\title{
Let the Bible Speak On the Woman Question: The Potrayal of the Girl Child in Literature and the Bible
}

\author{
Clemence Rubaya ${ }^{1}$, Mutonhori Tapiwanashe, Mabovula, $\mathbf{N}$ \\ Curriculum Studies Dept, Communication Studies, GREAT ZIMBABWE UNIVERSITY \\ * Curriculum Studies Dept- Religious Studies, GREAT ZIMBABWE UNIVERSITY \\ Walter Sisulu University, RSA
}

\begin{abstract}
The interest of this paper is narrowed on a comparative investigation of the portrayal of the girl child in both the Bible and literary works of art where special reference will be made to Buchi Emecheta's novel, The Bride Price and Yvonne Vera's Under the Tongue in order to discover whether the girl child's experience reflects the well-documented subjugation of women in general or hers is a unique experience, specific for her. The study acknowledges that while the larger percentage of focus of many writings on gender disparities has concentrated on the adult woman, comparatively little attention has been directed onto the girl child. By including the Bible as part of its study sample, the paper wishes to trace, ascertain and contribute to the question on whether malefemale gender dichotomy is traceable to the bible, making it a divine mandate or this is man-made as highlighted by de Beauvoir(1949) that "one is not born but becomes a woman." This library based study is informed by Feminism in its search for an explanation of how the girl child has been portrayed in the aforementioned sources. The researchers have discovered that both the Bible and literary art project a 'victim-image' of the girl child whose subjugation and existence of privation reflect clipped and curtailed human rights and privileges when compared to her compatriot, the boy child. The study has also discovered that because the girl child is female, her patriarchal subordination and subjugation can not be looked at as totally divorced from the general negation of the womenfolk though her experiences are worse and more harrowing than those of the older woman, given her tender age, inexperience and innocence. The conclusion of the study is that the little girl suffers a double yoke under the combined aggression of both men and older female ambassadors of the patriarchal machine. The research has also exposed as false the patriarchal myth that views girls as made up of inferior intellect.
\end{abstract}

KeyWords: Gender, Feminism, Patriarchy, Subjugation

\section{BACKGROUND}

The patriarchal subjugation of the woman is such a topical issue today the world over that several researches with a vested interest in the inequality between sexes have flooded the shelves (Rubaya and Gonye, 2011; Rubaya and Viriri, 2012). Controversy on whether the imbalance between sexes is a divine prescription or a cultural construct has remained largely unanswered even today. For instance, the renowned French feminist, Simone de Beauvoir (1949) who arguably 'fathered' the Feminist movement argues that, "one is not born, but rather becomes a woman... It is civilisation as a whole that produces this creature." Her contention here is that femininity is neither God-given nor a product of biology but a man-made phenomenon which is constructed by society. Becoming a woman in this context implies appropriation of such qualities as docility, submissiveness and subservience to the towering male figure.

Beauvoir's view above, however, sharply contrasts that held by Timothy Mubhawu, a former Zimbabwean Member of Parliament for Tafara-Mabvuku who in parliament, as quoted in the Herald newspaper, stated, "I stand here representing God Almighty. Women are not equal to men" (The Herald, Thursday 5 October 2006). Analysis of Mubhawu's comments shows his subscription to the argument that inequality between sexes is divinely willed and not a construct. Such a view held by a representative of the people, both men and women, and an esteemed member of society in the twenty-first century is an echo of the aged view held many centuries ago which finds voice through Queen Victoria who, in a letter to her daughter who at that time was recently married, is reported by Justin M'Carthy to have stated, “...the woman's devotion is always one of submission... though it cannot be otherwise as God has willed it so."Unlike Simone de Beauvoir, both Mubhawu and Queen Victoria, though separated by time and

${ }^{1}$ Corresponding Author: crubaya@gmail.com 
space, are united by their stated view that the woman's role is to be accepted unquestioningly as divine will. This presses home the fact that disagreements still rage today over "The Woman Question" as Abrams (1979) calls it.

The current researchers' interest in this study has been awakened by the debate shrouding the subject as they, too, feel challenged to research on the subject, find out and share their findings about this age-old multi-faceted topical issue through an examination of the portrayal of the girl child in both literary works of art and the Bible. The researchers feel that little attention has been directed onto the girl child when compared to the adult woman and they, therefore, wish to concentrate on this neglected area so as to expose the ignored multi-dimensional plight of the girl child in particular, and all women in general. It is their feeling that to understand the plight of the adult woman, there is need to trace societal views of the woman when she is still a child, before she blossoms into womanhood and adulthood.

\section{RESEARCH METHODOLOGY}

This study is a library based research which explores the biblical and literary portrayal of the girl child. Sections of the Bible which help illustrate the portrayal of the girl child in the Word of God will be purposively sampled and used to complement information from two novels by female writers, The Bride Price and Under the Tongue. The basis for selecting the above literary texts is that they are written by women writers who are supposed to have an intimate experiential understanding of what girls go through as they grow up. Emecheta, author of The Bride Price, is a female West African novelist whose literary works most critics rate highly. On the other hand, Vera who has written Under the Tongue heralds from Southern Africa and an inclusion of her work will give balance to this study by looking at ideas from different parts of the African continent on the same subject.

Any other relevant secondary sources will also be used to enrich the whole study. The researchers have decided to rely on the 'soft' evidence of library research and not 'hard' quantifiable data from interviews or questionnaires because in the words of Lukacs quoted in Eagleton (1986), literature is a reflection of society. This implies that literature and life constitute a reverse reaction indicating that information collected through document analysis is valid and trustworthy since no literary work can be torn from its specific social and historical milieu which gives it its verisimilitude. To explicate these issues, the researchers will establish a theoretical framework, which will help illuminate the concerns of the study on the experiences of the girl child.

\section{THEORETICAL FrAMEWORK}

This study can be adequately understood if, among other means, the Feminist literary theory which puts the woman at the centre of its enquiry is employed. The Feminist literary theory bemoans the fact that patriarchy tips the social scales in favour of the male, creating a sub-human being in the female. In the words of Susan Searing, the argument put forward by the Feminist literary theory is that, "The inequality of sexes is neither a biological given nor a divine mandate, but a cultural construct". This makes Feminism some kind of theoretical and political struggle for the recognition of the claims of women to equal rights with men. It is with this in mind that Moyana (1987:5) argues that the Feminist movement, "...seeks to reinterpret and to change the world's thinking of both men and women about themselves." Her argument thrusts the woman question at the centre of Feminist enquiry and, thus, the Feminist literary theory can aptly help illuminate and inform on the concerns of this current research investigation into the portrayal of the girl child in both the Bible and literary art because the girl child's plight is not divorced from the general condition of all women. Despite its uniqueness, the plight of the girl child remains a gender issue because it also originates from and participates in the larger efforts of Feminism to liberate females from the fetters of patriarchy.

While Feminism views the relegation of women to second class status as a cultural construct, some theologians posit that gender imbalances are a divine mandate. They argue that it has never been God's plan for males and females to assume equal social positions. To authenticate and entrench this argument, most quote Ephesians 5:22-24 which states: "Wives, submit yourselves unto your own husbands...For the husband is the head of the wife...Therefore...let the wives be....in everything." From this quotation, it would appear that the Bible appropriates a superior position to the male, making the 'headless' female submissive thereby suggesting that sexual inequality is a product of divine will that cannot be questioned. Elizabeth Rigby subscribes to this argument as she argues that disputing and challenging gender inequality amounts to "ungodly discontent." This entrenches the argument that is given by some that God has ordained that males be superior to their female counterparts. It is with this theoretical framework in mind that this paper now attempts to investigate the experiences of the girl child in the aforementioned sources. 


\section{FINDINGS}

This investigation has revealed that both the Bible and the novels under study project a "victim-image" of girls as people with trapped existence as there are various cultural and social limitations imposed on them making the girl child a victim of different socio-religious factors of her time. In the Bible, she is largely a victim of the Jewish patriarchal oppressive structures that were the basis of gender inequalities as she was brought up to think and act according to the patriarchal traditions passed down through the generations. This was compounded by the institution of slavery coupled with the prevailing military conflicts which saw the girl child becoming a victim of abuse.

Below is a thematic presentation of the study's findings which help illuminate the plight of the girl child:

\section{GirLS AS SEX OBJECTS}

This study has discovered that both literature and the Bible highlight how the girl child is socialised into valuing wifehood and motherhood as the acme of female attainment. The Old Testament biblical texts show how the girl child grew up in a culture where virginity of the girl child was highly esteemed. This means that the girl child was expected to avoid premarital sex and hence retain her virginity. A reading of one biblical chapter, Deuteronomy 22: 13-21, actually shows that losing virginity by the girl child is deemed criminal. For instance, a man could have his wife killed by claiming that she lost her virginity prior to their marriage. Following this accusation, the bride was required to prove her virginity by producing visible evidence such as a blood- stained garment. If the bride failed to prove her virginity, she was stoned to death. However, if the accusation was false, the husband was flogged and forbidden to divorce the wife. While a man faced flogging, the woman, on the other hand was confronted by a spectre of death. The disparity of the judgments pronounced on the two sexes is further heightened by the fact that, male virginity is a subject conspicuously absent in the Bible but is only discussed in camouflaged general terms such as 'Thou shalt not commit adultery' which applies equally to both sexes and is not particular to a given sex [Exodus 20:16].

Close scrutiny of the value of virginity for the little girl reveals that the preservation of her virginity is not for her sake but for the satisfaction of her male counterpart on the marriage night. In this way, girls were inculcated into a culture that valued wifehood. Carby (1987:26) portrays this picture when she posits that:

...wifehood and motherhood were glorified as the purpose of a woman's being; the home was the sphere of all a woman's actions. The prime objective of a woman's life was to obtain a husband and then to keep him pleased...

Consequently, girl childhood becomes a preparatory phase for this later station in life as girls are tutored in their infancy towards acceptance and assumption of this future role. The girl child is, therefore, fettered and not free to self-define since the gender role of becoming a wife and a mother towards which she is tutored are constructed in patriarchy to serve the interests of the man.

Evidence of this study also shows how girls are reduced to sexual objects, victims of rape and sexual abuse in order to satiate the male sexual appetite. The girl child is subjected to rape by males in a number of incidences in the Bible. As an example, in the biblical book of Judges $19 v 16-30$, some men in the city wanted to gang rape a visiting Levite. However, the owner of the house opted to save men from rape by offering his virgin daughter and the guest chose to offer his concubine so that the men could rape them. The concubine was later discovered dead after the sexual assault. This draws parallels with the Genesis story of Lot in Sodom who protects the two male strangers from a crowd of gay men who wanted to gang rape the visitors. In his words, as recorded in Genesis 19:6-8, the biblical character, Lot, actually says to the marauding homosexual rapists, "No my friends. Don't do this wicked thing. Look, I have two daughters who have never slept with a man. Let me bring them out to you, and you can do what you like with them. But don't do anything to these men..." (NIV). Lot shows little thought for his daughters whom he is ready to lay on the sacrificial altar in his desire to protect fellow men. The fact that men could allow their daughters to be sexually abused by several rapists shows callous devaluation of the girl child who was viewed as inferior, expendable and of little value.

As if that is not enough, the when the Bible character, Moses' army defeats the Medianites in a war and captures many war prisoners, he instructs his solders to kill the surviving men and boys, as well as any woman who had already slept with a man. However, "all the women children that have not known a man by lying with him, keep alive for yourselves." Keeping the girls alive is not out of kindness but so as to ravage their virginity. One could be certain that the women children referred to in the text included girl children who, as human trophies of war, were exposed to sexual violence. The passage also indicates that God got a share of the spoils as He was given thirty-two 
virgins who were later handed over to the priests (Numbers 31 v40-41). Most probably these girl children would be raped by the priests. Thus, the rights of the girl child were violated even in biblical times as these biblical texts paint a picture of how the girl child's marital choices could be ignored.

Literature also discusses a similar theme. In Under the Tongue, Vera chronicles a painful story of a girl child, Zhizha, who is raped by her own father, Muroyiwa. The weight of the novel's inquiry is pinned on the heart-rending experiences of a girl-child 'whose grief is the father's lust.' As readers, we are shocked by this incestuous rape but what aggravates the pain is that the child narrator is so young and innocent that she has no language to describe what her father has done to her. In her attempt to describe her ordeal, Zhizha says, "Father falls on my legs parted, spread on the cold floor....A throbbing hard and horrid passes between my legs, searing, tearing (p.105)." Zhizha is not alone in her experiences of domestic aggression as another child narrator, Pecola, in Toni Morrison's The Bluest Eye reveals the dehumanization of the girl child as a creature. Like Zhizha, Pecola is raped by her own father,too, and Morrison (1994:171)) notes how "the victim does not have the vocabulary to understand the violence or its context..." She is used and abused by the father to quench his sexual appetite thereby reducing the girl child to a sex object. Morrison (1994:168) shows how "some aspects of her [Pecola] woundability were lodged in all young girls." Thus, Pecola and Zhizha's experiences are not unique to them but to all girl children. Unfortunately for Pecola, instead of pitying her, the older generation woman castigates her for the rape pointing out that "the girl was always foolish... [and] carry some of the blame (p.148, 9). Her mother even beats her while fellow girl children in this novel, Frieda, Claudia and other small girls "were embarrassed for Pecola, hurt for her, and... felt sorry for her (p.149). This underscores the argument that the girl child's life is dismissed, trivialized and misread, implying that she suffers a double yoke as she is at the mercy of both men and fellow women.

\section{The Girl ChILd AND Loss OF Identity}

Apart from the above, the skewed sexual landscape that elevates maleness while relegating femaleness has also given birth to the loss of individuality and identity by the girl child. Throughout her life, this young female is continually moving in a social continuum where her identity constantly changes. At birth she is called 'daughter' and bears the name of her father, which she will one day shed for another male's. Spillers (1990:127) paints this scenario when she argues that: "...the patriarchal daughter remains suspended as a social positionality between already established territories." The fact that the daughter 'remains suspended' echoes the argument that she has no identity of her own and lacks free will. Spillers (1990:127) calls this the law of high patriarchist culture in a heterosexual synthesis. She adds: “....daughter maintains status only in so far as she succeeds in disappearing, in deconstructing into 'wife' and 'mother' of his children." In a metaphorical sense, then, the girl child is socially, intellectually and psychological murdered and banished so that she becomes more or less a willing tool in the text of a cultural conspiracy. Patriarchal society plants and instutionalises in the female child that concept of generational continuity where gender roles are passed on from one generation to the next, (Rubaya, 2007).

Vera, in her book, Without a Name dramatizes the same idea of loss of identity by a young woman. The mere title of the novel itself is an adequate statement that voices namelessness and loss of individuality. The narrator is a girl child who bemoans her vulnerability that causes her to literally fall apart as she, too, can no longer identify herself.

Namelessness for girls is not a preserve of literary art as the Bible is also awash with stories of numerous unnamed girls in the Biblical history. In the book of 2 Kings 5, the little slave girl who saves the life of a Syrian Army General, a mighty man of valour in the name of Naaman, remains nameless. Naaman, though frail and eaten away by disease, has a name, yet, the identity of this healthy girl whose contribution is great remains buried under the debris of obscurity. The namelessness state of the slave girl underscores a diminished social construct of all girl children in general and this girl child in particular. This Biblical text, with its primary focus on the man, is also silent on what happened to this selfless girl child after Naaman was healed and readers are left wondering whether she got any reward for playing such an important role. One wonders whether she remained a slave after helping Naaman escape his own slavery from the curse of leprosy or she was elevated. Such silence alone and the nameless nature of the portrayal of this important girl, whether by design or default, is a loud statement that captures how the girl child is generally elbowed from the centre and thrust to the periphery. In other words, the Biblical text shows male centredness in the sense that the story of Naaman's cure from leprosy takes centre stage while details of the life of the slave girl are overlooked.

Another controversial instance showcasing the insignificance of the girl child is enveloped in the biblical chapter of Proverbs 22:6 that reads "Train up a child in the way $\underline{H E}$ should grow: and when $\underline{H e}$ is old, $\underline{H e}$ will not depart from it (emphasis supplied)." It is clear from this biblical injunction that the biblical picture of a child is exclusively male. 
Hence, one can argue that both the Bible and literary works of art concur in their portrayal of a caged existence for the girl child who is literally absent even in her presence.

\section{GIRLS AS THE SECOND SEX - INFERIOR TO BOYS}

Both the Bible and literature also show how the girl child is shoved to the bottom of the social heap while the boy child enjoys undivided attention. As an example, Emecheta 's description of the girl child, Adah, in her novel, Second Class Citizens is charged with pain as it reveals patriarchal intolerance of the birth of the girl child when she writes:

She was a girl who had arrived when everyone was expecting and predicting a boy. So, since she was such a disappointment to her parents, to her immediate family, to her tribe, nobody thought of recording her birth. She was so insignificant.

This underscores the argument that the girl child can only exist in a private peripheral sphere, confined by gender attitudes to an alienated existence. In another literary masterpiece, The Bride Price, Emecheta transports the reader up a similar theme as she dramatizes the same idea where another girl child, Aku-nna, knows that "she was too insignificant to be regarded as a blessing to this unfortunate marriage." After her parents get their second child, a son, Aku-nna remains the 'invisible' child and her father "....would remind Ma Blackie that having paid this heavy bride price.... what had he to show for it all - an only son!" In the eyes of Ezekiel, the father, Aku-nna is non-existent because she is only a girl and that is why he speaks in tones that suggest he has only one child, "an only son!" This treatment of the girl child reduces her to a disgrace and a nonentity in the eyes of the society.

Yvonne Vera, in Under the Tongue, also broaches the same subject of societal preference of a boy child to the girl child when she describes Grandfather's tirade towards Grandmother for 'her failure' to bring forth a baby son in the following terms: "Your womb is rotten. I married a womb filled with termites..." although this marriage is already blessed with a baby girl, the essence of such a tirade is to dehumanize the girl child who is a product of this same womb. If the 'womb is rotten', then what comes out of it is equally rotten. Similarly, the image of 'a womb filled with termites' serves to reduce the girls who are born from this same womb to the level of termites. Thus, the girl child is dehumanized.

Vera provides a sharp contrast in the reaction of Grandfather when his wife finally bears him a son. Grandmother tells Zhizha: "A boy arrived into our decaying like one drop of cold rain and the waiting left the eyes of your grandfather." Therefore, according to Vera, marriages can literally decay and disintegrate if the wife is not 'fortunate' enough to give birth to a boy child. Tsitsi Himunyanga-Phiri in The Legacy (1992) propounds the same argument when she discusses Moya's plight. When she continues to give birth to girls, Moya says: “...my motherin-law told me point blank that I had disappointed them by not giving them a grandson....The family needed boys ...What good were girls?" All this demonstrates how the boy child is prized while the girl child - a disappointment is alienated. The life of a girl child can best be understood in existential terms as: "......an isolated existent who is cast out into an alien universe, to conceive of the universe as possessing no inherent human truth or meaning...." This depicts an existence which is hollow and empty of meaning. The meaninglessness of life for girls is grounded in the fact that they are born of parents and to a society that neither appreciates nor acknowledges their existence. Emecheta's Aku-nna has no other friend to lean on except Chike, her slave boyfriend, with whom interaction is forbidden. Dickens's Florence in the book Dombey and Son, on the other hand, has nobody to lean on except her baby brother yet her father commands her: "Don't touch him!" The meaninglessness of life for Florence is viewed in that she is reduced into conversing with Diogeness, a dog, because she has no human companionship. Emecheta, on the other hand, dramatizes Aku-nna's alienation and how life loses its meaning for her when she writes:

She had lost her father. Her mother was literally, lost to her, so deeply was Ma engulfed in the affairs of Okonkwo's household....her brother... as a boy... was allowed to do what he liked...It came to Aku-nna now that she was completely alone.

This demonstrates a harrowing experience where the girl child is dumped into a social abyss of nonentity.

Emecheta (1988) further entrenches the above theme in another of her novels, The Joys of Motherhood, where one of her male characters, Nnaife, laughs loudly after his wife gives birth to her first twins who happen to be girls. Nnaife asks his wife, "Nnu Ego, what are these? Could you not have done better?" (p.127). The use of the word "these" by Nnaife to refer to his own blood dehumanizes the children and equates them to objects. Perhaps, this explains why we see Nnu Ego later in the story, worn out by physical labour, crawls to inspect the sex of another new born child, consumed by the fear of giving birth to the wrong species. Surprisingly, when she discovers that the 
baby had already died, the fact that "it was a girl... [lessens] her sense of loss." This further demonstrates how the girl child is regarded as inferior to her male counterpart whose birth is celebrated.

Evidence in the Bible also reflects and buttresses the same theme where the baby girl is treated as of inferior fibre to the baby boy. For example, the Levitical laws of the Jews attach less material worth to the girl child than they do to the baby girl. While a boy child within the age range from one month to five years was worth five shekels, his female counterpart had less monetary weight at three shekels as brought out in Leviticus 27:6. This reflects how, in material terms, the Jewish law suggests that the girl child was less valuable than the boy child. Perhaps this explains why the girl child was not deemed worthy to be included in the census which only counted male infants over the age of one month and men (Numbers 3:15). All this is a form of biblical gender discrimination affecting the girl child in its infancy which perhaps informs societal views of the girl child as inferior to the boy child. Biblical texts are largely biased towards males as we are given detailed accounts of life histories of male characters from their boyhood to adulthood. These include stories of young boys like Moses, Samuel and David whose biographies are traced from very tender ages. Female characters, on the other hand, are not given detailed accounts of their life histories. As already seen in this article, in some cases the biblical accounts do not even mention the names of the girl child characters, just like the names of Naaman's slave girl and Jairus's daughter are not mentioned. Furthermore, the life histories of the daughters of the patriarchs are not given. Thus, gender bias towards males is seen in the fact that in the Bible, God is male, Jesus is male and all the apostles in the New Testament are male. Such loud and glaring absence of the female half of society from the biblical story entrenches the fact that the girl child is exposed to a religion which is largely masculine in outlook and which emphasises male dominance and female submissiveness. The girl child is brought up to believe that her gender is inferior and that male characteristics are of supreme value.

\subsection{The Girl Child And Ritual Purity}

The issues of cleanliness and uncleanliness also serve as a notable divide between the boy child and the girl child. Biologically, girls menstruate, not out of choice, but as a normal response to the laws of nature. Unfortunately, in the Bible, the Jewish laws view the girl child who is menstruating as ritually unclean. Anyone or anything which comes in contact with her during her menstrual period is polluted and hence becomes unclean (Leviticus 15:19-30). Contact with her is prohibited for seven days or until the bleeding stops. The girl child is, in this way, banished and segregated against during certain periods of her life because of natural biological processes, a feat never experienced by the boy child.

Furthermore, the biblical book of Leviticus projects the inhibitions of the Jewish law which certified a woman unclean for seven days if she gave birth to a baby boy and must then be purified for thirty three days. On the other hand, if she gave birth to a girl child, the period of confinement is doubled to fourteen days while that of ritual cleansing is doubled to sixty six days (Leviticus 12:1-5). A cursory analysis of such a law is indicative of how girls are regarded as dirtier than boys, in fact, double unclean and hence are believed to pollute more their mothers than the boys.

In the end, maleness is esteemed while femaleness is viewed contemptuously. This label of inferiority attached to the girl child from infancy becomes a psychosocial handicap that haunts her throughout her adult life as well as narrowing down opportunities for her, with the aim of producing a 'decent' woman capable of being a worthy wife to the man.

\subsection{Commercialisation of the Girl Child}

However, it appears that to argue that the girl child is totally valueless in the eyes of both the Bible and literary art would be misrepresentation of reality. This study has found out that there are instances when the girl child is viewed in great esteem. For example, the New Testament chronicles a story of a slave girl child who is greatly valued by her master because she is of great benefit to her owners as recorded in Acts 16:16-24. This young girl is double slave as she is not only slave to her human master but is also controlled and pestered by an evil but powerful fortune telling spiritual force that gives her occult powers to divine thereby becoming an important source of revenue for her masters. However, when Paul, filled with the Holy Spirit, exorcises and banishes this evil influence so as to unchain and liberate the young girl, he and his companion, Silas, are hauled before the courts by the slave girl masters. The masters of the slave girl seem to be concerned more about the economic value of the girl child than her welfare. Thus, Paul's' exorcism of the spirit, though it might have had a liberating effect on the girl child, angers the owners who have lost a source of income. Thus, the biblical text portrays the slave girl as possessing no value in her personhood but some commercial value, like an object of merchandise. The same argument is brought out in 
literature through Emecheta's novel, The Bride Price, where Aku-nna, a girl of thirteen, knows fully well that she is "too insignificant to be regarded as a blessing to this [her parents'] unfortunate marriage" (p.3). Nevertheless, her name brings out the kind of value she has because her father, Ezekiel, "named her Aku-nna, meaning literally 'father's wealth', knowing that the only consolation he could count on from her would be her bride price" (p.4). From her birth, Aku-nna carries a name that camouflages her human worth but showcases her commercial worth because her father envisages the bride price he is likely to fetch from Aku-nna's future marriage as his stepping stone towards the achievement of "the Eze title which could be his as soon as he had sufficient money" (p.72). On the other hand, Aku-nna's mother, Ma Blackie, later in the story feels that Aku-nna's "bride price would be needed very quickly to see her mother through her period of confinement" as she is now pregnant and needs money (p.127). Such a view demonstrates and underlines the commodification of the girl child who is reduced to merchandise with commercial value, an object to be sold in marriage for the benefit of others. In other words, the girl child can be viewed as a ticket for men and older women to opulence and a commodity to feather their pockets.

\section{CONCLUSION}

This investigation into the portrayal of the girl child through the eyes of literary art and the Bible has shown that the experiences of the girl child are an echo of the experiences of the older woman. Her voice of anguish can not be construed as a separate voice from that of the generality of womenfolk at large but a reverberation of it. However, it is clear from the above exegesis that the girl child's predicament is worse than that of the older woman in the sense that hers is a double yoke as she suffers from both man and woman who is complicit to the subjugation of her younger mate. What makes the trials and tribulations of the girl child especially excruciating is her innocence and lack of experience as well as the fact that she is also harangued by a fellow woman.

This study has shown that both the Bible and literary art concur in their portrayal of the girl child as inferior to the boy child given the observed unrivaled inattention reserved for the girl child, vis-a-viz the love for the boy child. In the majority of reviewed cases in this study, the girl child loses her identity right from birth as she remains nameless, a pointer to her valuelessness. Her value has been discovered to be commercial since she can be bought or sold, to benefit her male master, and at times the older woman. This reduces girl children to merchandise and sex objects whose virginity should be preserved at all cost for the satiation of her male counterpart on consummation night.

\section{RECOMMENDATIONS}

Basing on the findings of this study into the portrayal of the girl child through the lenses of the Bible and literary works, it is recommended that studies on the plight of women treat the experiences of the girl child as unique and different from those of the older women. This is because some older women have been found to act in cohort with men in the oppression of the girl child, making her suffer a double yoke from these twin engines of patriarchal hegemony.

The study further recommends that, given the years of unrivaled attention heaped on the boy child, there is need for deliberate effort to embrace gender skewed policies that are calculated to advantage the girl child so as to create equity between the sexes and help in the correction of a wrong of the ages.

\section{REFERENCES}

[1] Abrams M. H (ed) The Norton Anthology of English Literature. (New York: W. W Norton and Company, 1979$) 1650$.

[2] Carby, H. V. (1987) Reconstructing Womanhood: The Emergence of the Afro-American Woman Novelist. (Oxford: OUP, 1987)

[3] Cheryl Wall (ed) (1990) Changing Our Own Words: Essays On Criticism, Theory and Writing by Black Women. London: Routledge, 1990) 3.

[4] De Beauvoir, S. (1949) The Second Sex. London: David Campbell.

[5] Dickens, C. (1985) Dombey and Son. London: Macmillan.

[6] Eagleton, T. (1986) Marxism and Literary Criticism. London: Macmillan.

[7] Emecheta, B. (1988) The Joys of Motherhood. London: Heinemann.

[8] Emecheta, B. (1990). Second Class Citizens. Chicago: Heinemann.

[9] Emecheta, B. (1995) The Bride Price. Chicago: Heinemann.

[10] Himunyanga-Phiri, T. (1992) The Legacy. Harare: ZPH.

[11] Morrison, T. (1994) The Bluest Eye. London: Picador. 
American Research Journal of English and Literature, Volume 1, Issue 1, February 2015

ISSN 2378-9026

[12] Rosemary Moyana, "The Changing Role of Women in the Africa Novel" an unpublished M. A dissertation, (University of Zimbabwe, English Department, 1987) 5.

[13] Rubaya, c and Viriri, E. (2012) 'Breeding Patriarchal Patriots: the Place of Children within a patriarchal home' in CASAS, Occasional Paper No.67.

[14] Rubaya, C. and Gonye, J. (2011) 'The Third Sex: A Paradox of Patriarchal subjugation of the weaker man' in International Journal of English and Literature, vol. 2.

[15] Searing, S.E. (1985) Introduction to Literary Research in Women's Studies. London: Westview Press.

[16] Spillers, H.J. (1990) 'The Permanent Obliquity of an in (pha)llibly Straight” : In the time of the Fathers' in Cheryl Wall (ed) Changing Our Own Words: Essays on Criticism, Theory and Writing by Black Women. London: Routledge, 1990.

[17] The Herald, Thursday 5 October 2006.

[18] The Marked Reference Bible (1965) New York: Zondervan Publishing House.

[19] Vera, Y. (1993) Without a Name. Harare: Baobab Books.

[20] Vera, Y. (1996) Under the Tongue. Harare: Baobab Books. 